\title{
RESEARCH PAPER \\ Effects of physicochemical soil properties of five agricultural soils on herbicide soil adsorption and leaching
}

\author{
Claudio Alister, Manuel Araya, and Marcelo Kogan \\ Escuela de Ciencias Agrícolas, Universidad de Viña del Mar. Av. Agua Santa 7055. Viña del Mar, Chile.
}

\begin{abstract}
C. Alister, M. Araya, and M. Kogan. 2011. Effects of physicochemical soil properties of five agricultural soils on herbicide soil adsorption and leaching. Cien. Inv. Agr. 38(2): $243-251$. Once pesticides reach the soil, there are several factors that affect their soil behavior. To identify the principal soil and herbicide properties that control their adsorption and leaching, a study of five Chilean agricultural and forest soils was performed. Simazine, diuron, terbuthylazine and MCPA were applied to the top of $45-\mathrm{cm}$ tall by $12-\mathrm{cm}$ diameter disturbed soil columns, filled with either an Andisol, Ultisol, Entisol or one of two Inceptisol soils. After herbicide applications, each lysimeter received $24 \mathrm{~mm}$ of simulated rain every 24 hours for five days. Once water percolation stopped, the lysimeters were divided into five sections and herbicide concentrations were quantified using High Pressure Liquid Chromatography. Relationships between soil physicochemical properties, herbicide sorption (adsorption and desorption) and herbicide leaching were determined. All herbicides exhibited the least depth reached from the Andisol soil $(10 \mathrm{~cm})$ and the highest from the Ultisol soil $(45 \mathrm{~cm})$. The principal soil property that affected herbicide adsorption was the soil organic carbon content, specifically the fulvic acid-humins fraction. Soil leaching was related to the inverse of soil adsorption $(1 / K d)$, cation exchange capacity, humic substances content and herbicide $p K a$. These results suggest that it is possible to develop simple quantitative models to predict the soil-leaching properties of pesticides.
\end{abstract}

Key words: Diuron, fulvic acids, humic substances, MCPA, triazines.

\section{Introduction}

When a pesticide reaches the soil, a series of processes that control the persistence of this compound in the site of application occur. The degradation, volatilization, lixiviation and adsorption of the compound to the soil are considered among the main processes that are associated with the dynamics of a pesticide in soil. It

Received October 29, 2010. Accepted April 28, 2011.

Corresponding author: calister@uvm.cl is generally accepted that the leaching of a compound depends mainly on its degradation and its sorption to the soil. Therefore, most of the simple indexes used to evaluate the risk of pesticide leaching include degradation and sorption as the main factors (Laskowski et al. 1982; Gustafson, 1989; Spadotto, 2002), as well as some other soil parameters (e.g., density, organic carbon, soil humidity) in the case of more complex indexes (Rao et al., 1985; Meeks and Dean, 1990). However, according to some authors, adsorption and desorption are the phenomena that regulate the speed and magnitude of leaching, and a 
compound should not be affected by other processes while it is adsorbed to the humic-argillic system (Charnay et al., 2005; Papiernik et al., 2006). Thus, the incorporation of organic soil amendments increase the adsorption of some pesticides, decreasing leaching and increasing persistence. Nevertheless, as pluviometry is varied through simulated rain, persistence is modified, but not leaching, which indicates that adsorption itself could be a better signal of the deep movement of a pesticide compared with other processes, such as degradation (FouqueBrouard and Fournier, 1996; Muller et al., 2003; Alister et al., 2005; Kogan et al., 2007).

A study based on this information was carried out to determine the mobility of four herbicides in five different soils and the relationships of the physicochemical properties of the soils and the herbicides with the sorption and lixiviation of the herbicides.

\section{Materials and methods}

\section{Selected soils}

Five soils with different physicochemical properties were selected (Table 1). Analyses of the principal physicochemical properties $(\mathrm{CE}, \mathrm{pH}$, cation exchange capacity, organic carbon and texture) were made according to Kalra and
Maynar (1991). The methodology proposed by Rocha et al. (1998) and IHSS (2009) were used to determine the humic substances (HS), humic acids (HA) and fulvic acids + humins (FAH) fractions (Table 1).

\section{Disturbed soil columns}

Three 50-cm long by $12-\mathrm{cm}$ diameter PVC columns were filled to a depth of $45 \mathrm{~cm}$ with each soil, which were sieved previously to $<2 \mathrm{~mm}$. Conic base caps made of PVC were installed on these columns and then, filled with quartz sand before soil filling and hermetically fitted to the column. A glass wool cord was placed intermingled in the quartz sand and in direct contact with the soil of each column, allowing the water movement inside the column of disturbed soil to flow similarly as obtained naturally in the soil (Boll et al., 1992).

Once the columns were installed, a micro-aspersion system was arranged in the upper part of the columns and used to create a saturated soil environment. The selected herbicides were applied 48 hours after water percolation reached the bottom of the columns at doses equivalent to those indicated in Table 2. The herbicides were applied with a micropipette over the column surface using a concentric distribution of $5020-\mu \mathrm{L}$ drops, for a total volume of $1 \mathrm{~mL}$ of

Table 1. Physicochemical properties of the soils analyzed.

\begin{tabular}{|c|c|c|c|c|c|c|c|c|c|c|c|}
\hline \multirow{3}{*}{ Soil } & \multirow[b]{3}{*}{$\mathrm{pH}$} & \multirow{3}{*}{$\begin{array}{l}\mathrm{EC}^{1} \\
\mathrm{mS} \\
\mathrm{cm}^{-1}\end{array}$} & \multirow{3}{*}{$\begin{array}{c}\mathrm{CEC}^{2} \\
\text { meq } \\
100 \mathrm{~g}^{-1}\end{array}$} & \multicolumn{3}{|c|}{ Inorganic soil phase } & \multicolumn{5}{|c|}{ Organic soil phase } \\
\hline & & & & Sand & Clay & Loam & $\begin{array}{l}\text { Organic } \\
\text { matter }\end{array}$ & $\begin{array}{l}\text { Organic } \\
\text { carbon }\end{array}$ & $\begin{array}{c}\text { Humic } \\
\text { substances }^{3}\end{array}$ & $\begin{array}{l}\text { Humic } \\
\text { acids }^{3}\end{array}$ & $\begin{array}{c}\text { Fulvic } \\
\text { Acids } \\
+ \text { humins }\end{array}$ \\
\hline & & & & & & & & $\%$ & & & \\
\hline Andisol & 5.52 & 0.38 & 61.41 & 25.1 & 16.9 & 58.0 & 20.28 & 11.79 & 3.75 & 0.13 & 3.62 \\
\hline Entisol & 6.29 & 0.10 & 4.98 & 83.1 & 6.9 & 10.0 & 1.55 & 0.90 & 0.33 & 0.31 & 0.02 \\
\hline Inceptisol & 7.88 & 0.68 & 16.40 & 23.1 & 20.9 & 56.0 & 4.71 & 2.74 & 0.31 & 0.03 & 0.28 \\
\hline Inceptisol & 7.57 & 0.12 & 20.50 & 39.6 & 33.7 & 26.7 & 3.58 & 2.08 & 0.39 & 0.01 & 0.38 \\
\hline Ultisol & 5.50 & 0.03 & 28.62 & 7.1 & 16.0 & 76.9 & 0.86 & 0.50 & 0.14 & 0.01 & 0.13 \\
\hline
\end{tabular}

${ }^{1}$ Electrical conductivity.

${ }^{2}$ Cation exchange capacity.

${ }^{3}$ Humic substances, humic acids and fulvic acids + humins are expressed as their percentage of the organic carbon content. 
herbicide solution applied to each column. A daily rain of $24 \mathrm{~mm}$ was simulated for 5 days 24 hours after the application of herbicides, over a period of 4 minutes per event.

Two days after the water percolation stopped in the columns, each column was opened longitudinally by making two lateral cuts, exposing the soil profile, which was separated into five sections: $0-10,10-20,20-30,30-40$ and under 40 $\mathrm{cm}$. The herbicides were quantified by HPLC for each soil section (different depths).

\section{Quantification of herbicide}

For extractions, $20 \mathrm{~g}$ of soil were shaked at 300 rpm for 90 min with $40 \mathrm{~mL}$ of methanol. Subsequently, the extracts were filtered (paper Whatman No. 1) and dried in a rotary evaporator. The herbicide residues were resuspended in $1 \mathrm{~mL}$ of methanol and transferred to a $1.5 \mathrm{~mL}$ glass vial to be analyzed using high-performance liquid chromatography (HPLC; Hitachi Elite LaChrom L-2300 model) with a Diode Array Detector (DAD; Hitachi Elite LaChrom L-2450 model) fitted for reading wavelengths between 190 and $400 \mathrm{~nm}$. The HPLC was equipped with a LiChrospher ${ }^{\circledR} 100$ RP-18 5- $\mu$ m column of 125 $\mathrm{mm}$ long. The specific analytical conditions for each herbicide are listed in Table 3.

\section{Determination of adsorption coefficients}

The adsorption coefficient $(K d)$ and the desorption percentage were determined for each herbicide for each soil. A total of $6 \mathrm{~mL}$ of a 0.01 $\mathrm{M} \mathrm{CaCl} 2$ solution with an herbicide concentration equivalent to $50 \%$ of the solubility of each herbicide (Table 2) were put into $15-\mathrm{mL}$ capped polypropylene centrifuge tubes with 3 $\mathrm{g}$ of each soil. These suspensions were shaked for 8 hours at $180 \mathrm{rpm}$ at $21 \pm 1{ }^{\circ} \mathrm{C}$ in darkness.

Table 2. Physicochemical herbicide properties and environmental coeffcients ${ }^{1}$.

\begin{tabular}{|c|c|c|c|c|c|c|c|c|}
\hline \multirow{3}{*}{$\begin{array}{l}\text { Herbicide } \\
\text { Simazine }\end{array}$} & \multirow{3}{*}{$\begin{array}{c}\begin{array}{c}\text { Solubility } \\
\text { ppm }\end{array} \\
5.0\end{array}$} & \multirow{3}{*}{$\frac{p K a^{3}}{1.62}$} & \multirow{3}{*}{$\frac{\log K_{o w}{ }^{4}}{2.3}$} & \multirow{3}{*}{$\begin{array}{c}T D_{50}^{5} \\
\text { days } \\
60\end{array}$} & $K_{d}^{6}$ & $K_{o c}^{6}$ & \multirow{3}{*}{$\begin{array}{c}\text { GUS } \\
\text { Index }^{7}\end{array}$} & \multirow{3}{*}{$\begin{array}{c}\text { Rate } \\
\mathrm{kg} \mathrm{ha-} \\
2.5\end{array}$} \\
\hline & & & & & \multicolumn{2}{|c|}{$\mathrm{mL} \mathrm{g}^{-1}$} & & \\
\hline & & & & & 1.8 & 130 & & \\
\hline Diuron & 35.6 & -- & 2.87 & 75 & 16 & 1,067 & Transitional & 2.0 \\
\hline Terbuthylazine & 6.6 & 2.0 & 3.4 & 55 & 3.3 & 191 & Leachable & 2.5 \\
\hline MCPA & 29,390 & 3.73 & -0.81 & 25 & 0.5 & 110 & Transitional & 1.1 \\
\hline
\end{tabular}

${ }^{1}$ Source: http://sitem.herts.ac.uk/aeru/iupac/

${ }^{2}$ Water solubility at $20{ }^{\circ} \mathrm{C}$.

${ }^{3}$ Acid dissociation constant.

${ }^{4}$ Logarithm of the octanol/water partitioning coefficient.

${ }^{5}$ Half life.

${ }^{6}$ Adsorption and organic carbon adsorption coefficients.

${ }^{7} \mathrm{GUS}=\left(\mathrm{TD}_{50} *\left(4-\log \left(\mathrm{K}_{\mathrm{oc}}\right)\right)\right.$.

Table 3. Chromatographic parameters.

\begin{tabular}{|c|c|c|c|c|c|}
\hline Herbicide & Mobil phase & 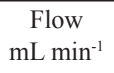 & $\begin{array}{c}\text { Column temp. } \\
{ }^{\circ} \mathrm{C}\end{array}$ & $\begin{array}{c}\text { Injection volume } \\
\mu \mathrm{L}\end{array}$ & $\begin{array}{l}\text { Retention time } \\
\text { min }\end{array}$ \\
\hline Simazine & $55 \%$ Acetonitrile & 1 & 30 & 60 & 1.73 \\
\hline Diuron & $60 \%$ Acetonitrile & 1 & 35 & 40 & 2.17 \\
\hline Terbuthylazine & $60 \%$ Acetonitrile & 1 & 35 & 99 & 3.94 \\
\hline MCPA & $\begin{array}{l}40 \% 13 \mathrm{mM} \text { Dihydrogen } \\
\mathrm{K}_{2} \mathrm{P}_{2} \mathrm{O}_{5} 60 \% \text { Acetonitrile }\end{array}$ & 1 & 35 & 40 & 3.10 \\
\hline
\end{tabular}


Finally, the tubes were centrifuged for $15 \mathrm{~min}$ at $5,000 \mathrm{rpm}$, and $1 \mathrm{~mL}$ of each supernatant was filtered through a $0.45-\mu \mathrm{m}$ fiberglass filter and used for quantification by HPLC, according to the conditions described above. The amount of adsorbed herbicide was calculated as the difference between the concentration of herbicide determined in the control tubes (herbicide solution without soil) and the remnant quantified in the solution after centrifugation. Equation 1 was used to determine the $K d$, where $K d$ is the adsorption coefficient $\left(\mathrm{L} \mathrm{kg}^{-1}\right), C s$ is the amount of adsorbed herbicide $\left(\mathrm{mg} \mathrm{kg}^{-1}\right)$, and $\mathrm{Ce}$ is the concentration of herbicide in solution after agitation $\left(\mathrm{mg} \mathrm{L}^{-1}\right)$.

$C s=K d^{*} C e$

After the supernatant sample was taken to determine the $K d$, the remaining supernatant was eliminated from each tube $(4.0 \mathrm{~mL})$ and the same volume was replaced with a $0.01 \mathrm{M}$ $\mathrm{CaCl}_{2}$ solution (without herbicide). These new suspensions were agitated for 4 hours following the procedure indicated above. This desorption step was performed three times, and the amount of desorbed herbicide was determined based on the total sum of the herbicide quantified in each wash, according to the methodology described before. Controls were included for the different herbicide solutions during the whole process, and no losses due to hydrolysis or herbicide adsorption to the polypropylene tubes were detected.

\section{Statistical analysis}

The program $\mathrm{SAS}^{\circledR}$ was used to analyze the results. Tests of multiple correlation (PROC CORR) were made among the soil parameters and the values of adsorption and desorption. The procedure of multiple linear regression (PROC REG) was used to quantify the effects of the physicochemical properties of the soil and the herbicides on leaching (the depth reached by an herbicide and the percentage that leached to below $10 \mathrm{~cm}$ ) using the stepwise procedure, with a variable input and output significance of $\mathrm{P}<0.1$.

\section{Results and discussion}

The adsorption of herbicides and their desorption percentages were variable, depending on the soil type (Table 4). The highest $K d$ values and lowest percentages of desorption occurred in the Andisol soil. In contrast, the lowest $K d$ values and the highest desorption percentages were determined for the Ultisol soil. Among the remaining soils studied, the Entisol soil had the second highest adsorptions for the four herbicides, with a texture composed with $83 \%$ of sand (Table 1).

The behaviors of most herbicides are generally influenced by the content of organic carbon in soil (Torrents and Jayasundera, 1997; Haberhauer et al., 2002; Hua Guo et al., 2008). The results of this work show that the effect of soil organic carbon (OC) on the adsorption of these herbicides might be explained by the composition of the humic substances (HS) present in this organic fraction. In general, the $K d$ values obtained for all of the herbicides in the Entisol soil, which had an OC content of $0.9 \%$, were only slightly higher than those for the two Inceptisol soils, with OC contents over $2 \%$. This may have been due to the similar HS contents of these three soils (Table 1 and 4). An OCadsorption relationship was observed when correlations between the coefficients of herbicide adsorption and the physicochemical properties of the soils were examined (Table 5), which is consistent with previous reports for simazine, diuron and terbuthylazine (Bollag and Meyers, 1992; Chefetz et al., 2004; Cao et al., 2008). Moreover, this work suggests that this relationship is specifically related to the fulvic acids + humins (FAH) content present in the humic fraction of the soil (Table 5).

The adsorption of MCPA, unlike the other three herbicides, had a high correlation with the $\mathrm{pH}$ and the cation exchange capacity (CEC) of the soils (Table 5). The $\mathrm{pH}$ values of the Ultisol and Andisol soils (Table 1) are close to the $p K a$ of MCPA (Table 2). Thus, the increases in the adsorption of MCPA in these soils could be associated with their higher CECs due to a higher 
Table 4. Adsorption coefficients $\left(K_{d}\right)$ and desorption percentages for each herbicide in different soils. Values are an average of three replications \pm standard error.

\begin{tabular}{|c|c|c|c|c|}
\hline \multirow[b]{3}{*}{ Soil } & \multicolumn{4}{|c|}{ Herbicides } \\
\hline & Simazine & Diuron & Terbuthylazine & MCPA \\
\hline & \multicolumn{4}{|c|}{$K_{d}\left(\mathrm{~L} \mathrm{~kg}^{-1}\right)$} \\
\hline Andisol & $2.108 \pm 0.059$ & $3.977 \pm 0.237$ & $3.741 \pm 0.324$ & $1.527 \pm 0.033$ \\
\hline Entisol & $1.090 \pm 0.065$ & $1.573 \pm 0.021$ & $0.750 \pm 0.030$ & $0.189 \pm 0.010$ \\
\hline Inceptisol & $0.875 \pm 0.043$ & $1.119 \pm 0.012$ & $0.694 \pm 0.012$ & $0.110 \pm 0.007$ \\
\hline Inceptisol & $0.617 \pm 0.038$ & $0.504 \pm 0.049$ & $0.551 \pm 0.005$ & $0.120 \pm 0.002$ \\
\hline \multirow[t]{2}{*}{ Ultisol } & $0.331 \pm 0.007$ & $0.319 \pm 0.020$ & $0.406 \pm 0.013$ & $0.798 \pm 0.021$ \\
\hline & \multicolumn{4}{|c|}{ Desorption (\%) } \\
\hline Andisol & $16.42 \pm 0.96$ & $9.83 \pm 0.38$ & $24.18 \pm 1.87$ & $24.81 \pm 3.69$ \\
\hline Entisol & $17.84 \pm 0.84$ & $25.43 \pm 1.02$ & $17.60 \pm 0.56$ & $34.66 \pm 1.60$ \\
\hline Inceptisol & $13.51 \pm 0.68$ & $27.52 \pm 0.67$ & $24.06 \pm 1.02$ & $71.40 \pm 1.19$ \\
\hline Inceptisol & $40.49 \pm 0.61$ & $40.89 \pm 1.06$ & $22.45 \pm 0.57$ & $59.18 \pm 0.90$ \\
\hline Ultisol & $60.49 \pm 5.82$ & $76.56 \pm 1.09$ & $74.72 \pm 0.32$ & $80.86 \pm 3.24$ \\
\hline
\end{tabular}

Table 5. Correlation matrix between adsorption coefficients $\left(K_{d}\right)$ or desorption percentages $(D)$ of each herbicide with physicochemical soil properties. The $\mathrm{P}$ values are given in parentheses.

\begin{tabular}{|c|c|c|c|c|c|c|c|c|}
\hline \multirow{2}{*}{ Soil properties } & \multicolumn{2}{|c|}{ Simazine } & \multicolumn{2}{|c|}{ Diuron } & \multicolumn{2}{|c|}{ Terbuthylazine } & \multicolumn{2}{|c|}{ MCPA } \\
\hline & $\mathrm{K}_{\mathrm{d}}$ & $\mathrm{D}$ & $\mathrm{K}_{\mathrm{d}}$ & $\mathrm{D}$ & $\mathrm{K}_{\mathrm{d}}$ & $\mathrm{D}$ & $\mathrm{K}_{\mathrm{d}}$ & $\mathrm{D}$ \\
\hline $\begin{array}{l}\text { Soil acidity } \\
(\mathrm{pH})\end{array}$ & $\begin{array}{l}-0.332 \\
(0.348)\end{array}$ & $\begin{array}{l}-0.261 \\
(0.464)\end{array}$ & $\begin{array}{l}-0.433 \\
(0.210)\end{array}$ & $\begin{array}{l}-0.159 \\
(0.659)\end{array}$ & $\begin{array}{l}-0.516 \\
(0.126)\end{array}$ & $\begin{array}{l}-0.511 \\
(0.131)\end{array}$ & $\begin{array}{l}-0.790 \\
(0.006)\end{array}$ & $\begin{array}{c}0.284 \\
(0.425)\end{array}$ \\
\hline $\begin{array}{l}\text { Electric } \\
\text { conductivity } \\
\text { (EC) }\end{array}$ & $\begin{array}{c}0.381 \\
(0.277)\end{array}$ & $\begin{array}{l}-0.529 \\
(0.115)\end{array}$ & $\begin{array}{c}0.334 \\
(0.344)\end{array}$ & $\begin{array}{l}-0.551 \\
(0.099)\end{array}$ & $\begin{array}{c}0.277 \\
(0.438)\end{array}$ & $\begin{array}{l}-0.418 \\
(0.228)\end{array}$ & $\begin{array}{l}-0.008 \\
(0.981)\end{array}$ & $\begin{array}{l}-0.021 \\
(0.954)\end{array}$ \\
\hline $\begin{array}{l}\text { Cationic } \\
\text { exchange } \\
\text { capacity (CEC) }\end{array}$ & $\begin{array}{c}0.664 \\
(0.036)\end{array}$ & $\begin{array}{l}-0.044 \\
(0.902)\end{array}$ & $\begin{array}{c}0.731 \\
(0.016)\end{array}$ & $\begin{array}{l}-0.258 \\
(0.470)\end{array}$ & $\begin{array}{c}0.648 \\
(0.042)\end{array}$ & $\begin{array}{c}0.095 \\
(0.792)\end{array}$ & $\begin{array}{c}0.935 \\
(0.0001)\end{array}$ & $\begin{array}{l}-0.321 \\
(0.364)\end{array}$ \\
\hline $\begin{array}{l}\text { Soil organic } \\
\text { carbon content } \\
\text { (OC) }\end{array}$ & $\begin{array}{c}0.906 \\
(0.0001)\end{array}$ & $\begin{array}{l}-0.462 \\
(0.177)\end{array}$ & $\begin{array}{c}0.924 \\
(0.0001)\end{array}$ & $\begin{array}{l}-0.667 \\
(0.035)\end{array}$ & $\begin{array}{c}0.842 \\
(0.002)\end{array}$ & $\begin{array}{l}-0.333 \\
(0.345)\end{array}$ & $\begin{array}{c}0.802 \\
(0.005)\end{array}$ & $\begin{array}{l}-0.625 \\
(0.053)\end{array}$ \\
\hline $\begin{array}{l}\text { Humic } \\
\text { substances (HS) }\end{array}$ & $\begin{array}{c}0.913 \\
(0.0001)\end{array}$ & $\begin{array}{l}-0.404 \\
(0.246)\end{array}$ & $\begin{array}{c}0.940 \\
(0.0001)\end{array}$ & $\begin{array}{l}-0.625 \\
(0.053)\end{array}$ & $\begin{array}{c}0.889 \\
(0.0006)\end{array}$ & $\begin{array}{l}-0.275 \\
(0.441)\end{array}$ & $\begin{array}{c}0.857 \\
(0.001)\end{array}$ & $\begin{array}{l}-0.677 \\
(0.031)\end{array}$ \\
\hline $\begin{array}{l}\text { Humic acids } \\
\text { (HA) }\end{array}$ & $\begin{array}{c}0.441 \\
(0.202)\end{array}$ & $\begin{array}{l}-0.505 \\
(0.136)\end{array}$ & $\begin{array}{c}0.404 \\
(0.245)\end{array}$ & $\begin{array}{l}-0.504 \\
(0.136)\end{array}$ & $\begin{array}{c}0.549 \\
(0.099)\end{array}$ & $\begin{array}{l}-0.420 \\
(0.226)\end{array}$ & $\begin{array}{c}0.003 \\
(0.991)\end{array}$ & $\begin{array}{l}-0.746 \\
(0.013)\end{array}$ \\
\hline $\begin{array}{l}\text { Fulvic acids } \\
\text { (FAH) }\end{array}$ & $\begin{array}{c}0.885 \\
(0.0001)\end{array}$ & $\begin{array}{l}-0.366 \\
(0.298)\end{array}$ & $\begin{array}{c}0.915 \\
(0.0001)\end{array}$ & $\begin{array}{l}-0.589 \\
(0.072)\end{array}$ & $\begin{array}{c}0.851 \\
(0.001)\end{array}$ & $\begin{array}{l}-0.242 \\
(0.499)\end{array}$ & $\begin{array}{c}0.865 \\
(0.001)\end{array}$ & $\begin{array}{l}-0.621 \\
(0.055)\end{array}$ \\
\hline Clay & $\begin{array}{l}-0.641 \\
(0.045)\end{array}$ & $\begin{array}{c}0.900 \\
(0.0001)\end{array}$ & $\begin{array}{l}-0.544 \\
(0.103)\end{array}$ & $\begin{array}{c}0.933 \\
(0.0001)\end{array}$ & $\begin{array}{l}-0.554 \\
(0.096)\end{array}$ & $\begin{array}{c}0.936 \\
(0.0001)\end{array}$ & $\begin{array}{c}0.138 \\
(0.702)\end{array}$ & $\begin{array}{c}0.770 \\
(0.009)\end{array}$ \\
\hline Loam & $\begin{array}{c}0.600 \\
(0.066)\end{array}$ & $\begin{array}{l}-0.560 \\
(0.091)\end{array}$ & $\begin{array}{c}0.584 \\
(0.076)\end{array}$ & $\begin{array}{l}-0.585 \\
(0.075)\end{array}$ & $\begin{array}{c}0.395 \\
(0.258)\end{array}$ & $\begin{array}{l}-0.364 \\
(0.299)\end{array}$ & $\begin{array}{c}0.381 \\
(0.276)\end{array}$ & $\begin{array}{c}0.170 \\
(0.638)\end{array}$ \\
\hline Sand & $\begin{array}{c}0.141 \\
(0.696)\end{array}$ & $\begin{array}{l}-0.416 \\
(0.231)\end{array}$ & $\begin{array}{c}0.061 \\
(0.865)\end{array}$ & $\begin{array}{l}-0.429 \\
(0.215)\end{array}$ & $\begin{array}{l}-0.218 \\
(0.545)\end{array}$ & $\begin{array}{l}-0.602 \\
(0.065)\end{array}$ & $\begin{array}{c}-0.426 \\
(0.218)\end{array}$ & $\begin{array}{l}-0.596 \\
(0.068)\end{array}$ \\
\hline
\end{tabular}


amount of this herbicide molecule being present in cationic form in these soils (Table 4). In the case of the Ultisol soil, the higher CEC is derived from the clay content, and in the Andisol soil, it is associated with the FAH content, which is highly related to the adsorption of herbicides like MCPA (Iglesias et al., 2009) (Table 5).

In general, the desorption process did not have a highly significant relationship with any parameter, except for the clay content (Table 5). The contrast between the high correlation of the desorption percentages of herbicides with the soil clay content, and not with the OC content, and the high correlation between the adsorption of these herbicides and the soil OC content (especially the HS content), but not the soil clay content, indicates the presence of a certain degree of hysteresis in the adsorption-desorption process. Therefore, the adsorption mechanism of the herbicides in these soils might differ from the desorption mechanism (Weber and Weiling, 1998). However, it is important to consider that the estimation of the desorption process is associated with a high degree of uncertainty because the adsorption-desorption process requires long periods of time to equilibrate and, in some cases, may take weeks or months to approach a real balance (Ball and Roberts, 1991; Weiling and Weber, 1998). Subsequently, the times for which desorption measurements were taken in this study might have been too short to achieve a realistic balance.

The leaching of herbicides in the studied soils depended on the type of soil and pesticide, as evident in Figure 1. Thus, none of the herbi- cides moved further than $10 \mathrm{~cm}$ deep in the Andisol soil; in contrast, all of the herbicides reached the maximum column depth in the Ultisol soil $(45 \mathrm{~cm})$. In the Entisol soil, only MCPA reached the $45-\mathrm{cm}$ depth. For the two Inceptisol soils, different patterns for simazine, diuron and terbuthylazine leaching were observed. Only MCPA showed a similar behavior in both soils.

The physicochemical properties of the soil $(\mathrm{pH}$, CEC, OC, HS, HA, FAH, clay, silt and sand), the physicochemical properties of the herbicides (solubility, $p K a$, and $\log ($ Kow $)$ ) and specific soil-herbicide parameters $(K d$ and \% desorption) that had the best correlations with the leaching of the different herbicide compounds were selected, and multiple regression equations were determined based on the selected parameters. The results of these regressions show that the leaching of the slightly ionic herbicides (simazine, terbuthylazine) and the non-ionic one (diuron) could be mainly explained by the inverse value of $K d(1 / K d)$, for both the depth reached and the amount mobilized to depths greater than $10 \mathrm{~cm}$ (Table 6). On the other hand, the $K d$ and HS content of the soil best explained the soil depth reached and the amount of herbicide leached beyond $10 \mathrm{~cm}$ for the more ionic herbicide MCPA (Table 5). When considering all of the herbicides, the main parameters determined by regression to explain the depth of movement and the amount of leaching below $10 \mathrm{~cm}$ included $1 / K d, \mathrm{CEC}$, HS and $p K a$. The inclusion of the herbicide $p K a$ in the regression might occur because three of four herbicides exhibit an ionic behavior (Table 2).



Figure 1. Leaching of four herbicides in disturbed soil columns. A) Andisol soil, B) Entisol soil, C) Inceptisol soil, D) Inceptisol soil and E) Ultisol soil. 
Table 6. Multiple regression models for the soil depth reached by herbicides and the amount leached below $10 \mathrm{~cm}$ of soil depth. Parameters included in the models are significant at $\mathrm{P}<0.1$.

\begin{tabular}{|c|c|c|}
\hline Herbicide & Regression models & $\mathrm{r}^{2}$ \\
\hline \multirow{2}{*}{ Simazine } & Depth $=12.200^{*}(1 / K d)+6.357$ & $\begin{array}{c}0.48 \\
(\mathrm{P}=0.025)\end{array}$ \\
\hline & Leached $^{1}=26.356 *(1 / K d)-6.59$ & $\begin{array}{c}0.49 \\
(\mathrm{P}=0.023)\end{array}$ \\
\hline \multirow{2}{*}{ Diuron } & Depth $=7.822 *(1 / K d)+0.246 *$ Clay +2.469 & $\begin{array}{c}0.95 \\
(\mathrm{P}<0.0001)\end{array}$ \\
\hline & Leached $^{1}=25.073 *(1 / K d)-11.481$ & $\begin{array}{c}0.80 \\
(\mathrm{P}=0.005)\end{array}$ \\
\hline \multirow{2}{*}{ Terbuthylazine } & Depth $=14.908 *(1 / K d)+5.626$ & $\begin{array}{c}0.69 \\
(\mathrm{P}=0.002)\end{array}$ \\
\hline & Leached ${ }^{1}=37.221^{*}(1 / K d)-8.131$ & $\begin{array}{c}0.76 \\
(\mathrm{P}=0.0009)\end{array}$ \\
\hline \multirow{2}{*}{$\mathrm{MCPA}$} & Depth $=-2.805 * K d-9.124 * \mathrm{HS}+48.518$ & $\begin{array}{c}0.99 \\
(\mathrm{P}<0.0001)\end{array}$ \\
\hline & Leached $^{1}=-14.421 * K d-19.006 * \mathrm{HS}+93.395$ & $\begin{array}{c}0.97 \\
(\mathrm{P}<0.0001)\end{array}$ \\
\hline \multirow{2}{*}{ All } & Depth $=2.578^{*}(1 / K d)+0.868^{*} \mathrm{CIC}-15.528^{*} \mathrm{HS}+2.556^{*} p K a+9.28$ & $\begin{array}{c}0.76 \\
(\mathrm{P}<0.0001)\end{array}$ \\
\hline & Leached $^{1}=5.921 *(1 / K d)+1.789 * \mathrm{CIC}-33.408 * \mathrm{HS}+7.616 * p K a+0.018$ & $\begin{array}{c}0.79 \\
(\mathrm{P}<0.0001)\end{array}$ \\
\hline
\end{tabular}

${ }^{1}$ Herbicide leached below 10 centimeters of soil depth.

According to the results, the herbicide-soil relationship, measured as the adsorption of herbicide to the soil, might be the main factor determining leaching (depth and mobilized mass) of herbicides. This is coherent with Crosby (1998), who has suggested that there should be a direct relationship between adsorption and the distance of pesticide movement in soil. Likewise, Kogan et al. (2007) found that simple indexes that include adsorption as the main parameter in their equation have better fits with the movement of simazine, diuron, oxifluorfen, pendimethalin and flumioxazin in the field than the indexes that include degradation, solubility and some hydraulic properties of the soil in addition to adsorption.

According to the results obtained in this study with disturbed soil columns, the phenomenon of herbicide leaching was primarily related to the adsorption of these compounds in the different soils, mainly due to their contents of fulvic acids + humins in the organic fraction of the soils, followed by parameters such as the cation exchange capacity, the content of humic substances in the organic fraction and the acid dissociation constant $(p K a)$.

Although these results may not be entirely extrapolatable to field conditions, in which the soil has different physicochemical conditions that would not be included in this study (especially in terms of structure), they help to determine the focus of the study of these relationships in natural conditions (undisturbed) to develop simple quantitative models to estimate pesticide leaching that consider only the adsorption of a pesticide to a soil and some other simple parameters.

\section{Acknowledgments}

The authors wish to thank FONDECYT (Chilean Fund for Science and Technology) for funding Project Number $\mathrm{N}^{\circ} 11085003$. 


\title{
Resumen
}

\begin{abstract}
C. Alister, M. Araya y M. Kogan. 2011. Relación entre la adsorción y la lixiviación de herbicidas en el suelo. Cien. Inv. Agr. 38(2): 243-251. Una vez que un plaguicida llega al suelo comienzan a actuar una serie de procesos que van controlando la permanencia de este compuesto en el sitio de aplicación. En base a esto se realizó un estudio en cinco suelos Chilenos para determinar el efecto de las propiedades físico-químicas del suelo y de los herbicidas sobre la lixiviación de esos compuestos. Simazina, diuron, terbutilazina y MCPA fueron aplicados sobre columnas de suelo disturbado de $45 \mathrm{~cm}$ de altura y $12 \mathrm{~cm}$ de diámetro llenas con suelos Andisol, Ultisol, Entisol y dos Inceptisoles. Una vez aplicados los herbicidas se simuló una lluvia de $24 \mathrm{~mm}$ cada 24 horas por 5 días. Cuando la percolación del agua terminó cada columna fue dividida en cinco secciones a las cuales se les determinó, la concentración de los herbicidas mediante HPLC-DAD. Todos los herbicidas mostraron su menor lixiviación en el suelo Andisol $(10 \mathrm{~cm}$ ) y la mayor en el suelo Ultisol $(45 \mathrm{~cm})$. El contenido de carbono orgánico fue la principal propiedad del suelo relacionada con la adsorción de los herbicidas, específicamente la fracción ácido fúlvico + humina. La lixiviación los cuatro herbicidas estudiados se relacionó con el inverso del coeficiente de adsorción $(1 / K d)$, capacidad de intercambio catiónico, fracción húmica del suelo y el pka de los herbicidas. Estos resultados permiten pensar en la posibilidad de desarrollar un índice cuantitativo simple para predecir la lixiviación en condiciones productivas.
\end{abstract}

Palabras clave: Ácido fúlvico, diuron, MCPA, substancias húmicas, triazinas.

\section{References}

Alister, C., R. López, and M. Kogan. 2005. Simazine dynamics in a vineyard soil at Casablanca valley, Chile. Pest Manag. Sci. 61: 1083-1088.

Ball, W., and R. Roberts. 1991. Long term sorption of halogenated organic chemicals by aquifer materials: Part 2. Intraparticle diffusion. Environ. Sci. Technol. 25: 1237-1249.

Boll, J., J. Selker, and T. Steenhuis. 1992. Fiberglass wicks for sampling water and solutes in the vadose zone. Soil Sci Soc Am Journal 56: 701-707.

Charnay, M., S. Tuis, Y. Coquet, and E. Barriuso. 2005. Spatial variability in ${ }^{14} \mathrm{C}$-herbicide degradation in surface and subsurface soils. Pest Manag. Sci. 61: 845-855

Chefetz, B., Y. Bilkis, and T. Polubesova. 2004. Sorption-desorption behavior of triazines and phenylurea herbicides in Kishon river sediments. Water Research 38: 4383-4394

Crosby, D. 1998. Environmental Toxicology and Chemistry. Chapter 4: Environmental Transport. p. 51-67. Oxford University Press, New York, USA.
Cao, J., H. Guo, M. Zhu, L. Jiang, and H. Yang. 2008. Effects of SOM, surfactant and $\mathrm{pH}$ on the sorption-desorption and mobility of prometryne in soils. Chemosphere 70: 2127-2134.

Fouque-Brouard, C., and J. Fournier. 1996 Adsorption-desorption and leaching of phenylurea herbicides on soils. Talanta 43: 1793-1802.

Gustafson, D. 1989. Groundwater ubiquity score: a simple method for assessing pesticide leachability. Env. Toxicol. Chem. 8: 339-357.

Haberhauer, G, B. Temmel, and M. Gerzabek. 2002. Influence of dissolve humic substances on the leaching of MCPA in a soil column experiment. Chemosphere 46: 495-499.

Hua Guo, J., H. Mei Zhu, L. Jiang, and H. Yang. 2008. Effects of SOM, surfactant and $\mathrm{pH}$ on the sorption-desorption and mobility of prometryne in soils. Chemosphere 70: 2127-2134.

Iglesias, A., R. López, D. Gondar, J. Antelo, S. Fiol, and F. Arce. 2009. Effect of pH and ionic strength on the binding paraquat and MCPA by soil fulvic and humic acids. Chemosphere 76: 107-113.

IHSS (International Humic Substances Society). 2009. International Humic Substances Society. Available online at: ihttp://ihss.gatech.edu/ 
ihss2/soilhafa.html (Website accessed: October 20th, 2009).

Kalra, Y., and D. Maynard. 1991. Methods manual for forest soil and plant analysis. Information Report NOR-X-319, Forest Canada Northwest Region, Northern Forestry Center. Edmonton, Alberta, Canada.

Kogan, M., S. Rojas, P. Gómez, F. Suárez, J.F. Muñoz, and C. Alister. 2007. Evaluation of six pesticides leaching indexes using field data of herbicides application in Casablanca Valley. Water Sci. Tech. 56: 169-178.

Laskowski, D., C. Goring, P. Mc Call, and R. Swann. 1982. Terrestrial environment. In: Environmental Risk Analysis for Chemicals. R.A. Conway (ed.). Van Nostrand Reinhold Co. New York, USA pp. 198-240.

Meeks Y., and J. Dean. 1990. Evaluating groundwater vulnerability to pesticides. Journal Water Resource Planning Manag. 116: 693-707.

Muller, K., R. Smith, T. James, P. Holland, and A. Rahman. 2003. Spatial variability of atrazine dissipation in an allophanic soil. Pest Manag. Sci. 59: 893-903.

Rao, P., A. Hornsby, and R. Jessup. 1985. Indices for ranking the potential for pesticide contamination of groundwater. Proceedings of the soil and Crop Science Society of Florida 44: 1-8.
Papiernik, S., W. Koskinen, P. Cox-Rice, S. Clay, N. Werdin-Pfisterer, and K. Norberg. 2006. Sorption-desorption of imidacloprid and its metabolites in soil and vadose zone materials. J. Agric. Food Chem. 54: 8163-8170.

Rocha, J, A. Henrique, and M. Furlan. 1998. An alternative methodology for extraction of humic substances from organic soils. J. Braz. Chem. Soc. 9: 51-56.

Spadotto, C. 2002. Screening method for assessing pesticide leaching potential. Pesticidas. Revista Ecotoxicologia e Meio Ambiente 12: 69-78.

Torrents, A., and S. Jayasundera. 1997. The sorption of noionic pesticides onto clays and the influence of natural organic carbon. Chemospehere 35: 1549-1565.

Weiling, H., and W. Weber. 1998. Hysteresis in the sorption and desorption of hydrophobic organic contaminants by soils and sediments. 1. A comparative analysis of experimental protocols. J. Cont. Hydrol. 31: 129-148.

Weber, W., and H. Weiling. 1998. Hysteresis in the sorption and desorption of hydrophobic organic contaminants by soils and sediments. 2. Effects of soil organic matter heterogeneity. J. Cont. Hydrol. 31: 149-165. 
